\title{
Identification of Species of the Genus Legionella Using a Cloned rRNA Gene from Legionella pneumophila
}

\author{
By NICHOLAS A. SAUNDERS, * TIMOTHY G. HARRISON, \\ NAFISA KACHWALLA AND ANTHONY G. TAYLOR \\ Legionella Reference Unit, Division of Microbiological Reagents and Quality Control, Central \\ Public Health Laboratory, 61 Colindale Avenue, London NW9 5HT, UK
}

(Received 11 December 1987; revised 18 March 1988)

\begin{abstract}
A cloned EcoRI fragment from Legionella pneumophila, which includes 16S and 23S rRNA genes, was used to identify bacteria belonging to the genus Legionella by hybridization to a series of species specific restriction fragments. Examination of the type strains of 28 species of legionellae gave different band patterns in every case. When further isolates of these species were tested the patterns obtained were usually either identical, or very similar, to those of the respective type strains. Thirty-one coded isolates were examined and of these 29 were allocated to the correct species. The remaining strains (a non-Legionella and a L. pneumophila) could not be identified using this technique. The rRNA gene probe method should be of great value in the identification of legionellae, particularly for those species which are at present very difficult to distinguish serologically.
\end{abstract}

\section{INTRODUCTION}

Legionellae are ubiquitous Gram-negative organisms, which can be isolated from most natural and man-made aquatic environments. Presumptive identification of Legionella species is easily made as these organisms fail to grow on conventional bacteriological culture media, but grow well on media such as buffered charcoal yeast-extract medium (BCYE), which have Lcysteine added. However, despite extensive studies of the genus, identification to the species level remains difficult.

At present there are at least 34 recognized species of Legionella as determined by DNA relatedness studies (Brenner, 1986). Although measurement of DNA homologies is recognized by many as the 'gold standard' in studies of bacterial taxonomy, it is both technically difficult and time-consuming. Furthermore, its use for the assignment of legionellae to the correct species requires that DNA from the unknown strain be tested against DNA of many members of the genus. Unfortunately, the biochemical and serological methods, which are of use in some cases for the identification of legionellae, do not always provide unequivocal results and consequently no effective alternative to DNA hybridization methods is currently available. Here we describe a method, based on the use of a cloned DNA fragment, to determine the species of bacterial isolates presumptively identified as belonging to the genus Legionella.

\section{METHODS}

Bacterial strains. Isolates of Legionella were cultured on BCYE agar at $37^{\circ} \mathrm{C}$ for $48 \mathrm{~h}$, harvested in saline $(0.85 \%$ $\mathrm{NaCl}$ ) and pelleted by centrifugation. Strains were obtained from the National Collection of Type Cultures, Colindale, UK, or are held here in the culture collection of the Legionella Reference Unit. The strains used in this study are listed in Table 1 . Their identity was known from reported DNA homology data (Table 1a) or was

Abbreviation: RFLP, restriction fragment length polymorphism. 
Table 1. Legionella strains examined in this study

(a) Strains identified by DNA homologies

\begin{tabular}{|c|c|c|c|c|}
\hline \multicolumn{2}{|l|}{ Species/serogroup } & $\mathrm{NCTC}^{*}$ & Strain & Reference \\
\hline Legionella pneumophila & Sgpl & 11192 & Philadelphia-1 ${ }^{\mathrm{T}}$ & Brenner et al. (1978) \\
\hline & & 11286 & Knoxville-1 & Brenner et al. (1978) \\
\hline & & 11191 & Pontiac-1 & Brenner et al. (1978) \\
\hline & $\operatorname{Sgp} 2$ & 11230 & Togus-1 & Brenner et al. (1979) \\
\hline & Sgp3 & 11232 & Bloomington-2 & Brenner et al. (1979) \\
\hline & Sgp4 & 11233 & Los-Angeles-1 & KcKinney et al. (1979) \\
\hline & Sgp5 & 11405 & Dallas-1E & England et al. (1980) \\
\hline & Sgp6 & 11406 & Chicago-2 & McKinney et al. (1980) \\
\hline & Sgp7 & 11984 & Chicago-8 & Bibb et al. (1983) \\
\hline & Sgp8 & 11985 & Concord-3 & Bissett et al. (1983) \\
\hline & Sgp9 & 11986 & IN-23-G1-C2 & Edelstein et al. (1984) \\
\hline & Sgpl0 & 12000 & Leiden-1 & Meenhorst et al. (1985) \\
\hline & Sgpl1 & 12179 & 797-PA-H & Thacker et al. (1986) \\
\hline & Sgpl2 & 12180 & $570-\mathrm{CO}-\mathrm{H}$ & Thacker et al. (1987) \\
\hline Legionella anisa & & 11974 & WA-316-C $3^{\mathrm{T}}$ & Gorman et al. (1985) \\
\hline Legionella bozemanii & Sgp1 & 11368 & WIGA $^{\mathrm{T}}$ & Brenner et al. (1980) \\
\hline & & 11369 & MI-15 & Brenner et al. (1980) \\
\hline & Sgp2 & 11975 & Toronto-3 & Tang et al. (1984) \\
\hline Legionella cherrii & & 11976 & $\mathrm{ORW}^{\mathrm{T}}$ & Brenner et al. (1985) \\
\hline Legionella dumoffii & & 11370 & $N Y-23^{T}$ & Brenner et al. (1980) \\
\hline & & 11402 & Tex-KL & Brenner et al. (1980) \\
\hline Legionella erythra & & 11977 & $\mathrm{SE}-32 \mathrm{~A}-\mathrm{C} 8^{\mathrm{T}}$ & Brenner et al. (1985) \\
\hline & & & LC217 & Author's unpublished data \\
\hline Legionella feeleii & Sgp1 & 12022 & WO- $44 C^{\mathrm{T}}$ & Herwaldt et al. (1984) \\
\hline & Sgp2 & 11978 & 691-WI-H & Thacker et al. (1985) \\
\hline Legionella gormanii & & 11401 & LS-1 $13^{T}$ & Morris et al. (1980) \\
\hline Legionella hackeliae & Sgpl & 11979 & Lansing- $2^{\mathrm{T}}$ & Brenner et al. (1985) \\
\hline & Sgp2 & 11980 & 798-PA-H & Wilkinson et al. (1985) \\
\hline Legionella israelensis & & 12010 & Bercovier- $4^{\mathrm{T}}$ & Bercovier et al. (1986) \\
\hline Legionella jamestowniensis & & 11981 & $\mathrm{JA}-26-\mathrm{G} 1-\mathrm{E} 2^{\mathrm{T}}$ & Brenner et al. (1985) \\
\hline Legionella jordanis & & 11533 & $B L-540^{T}$ & Cherry et al. (1982) \\
\hline Legionella longbeachae & Sgpl & 11477 & Long Beach- $4^{\mathrm{T}}$ & McKinney et al. (1981) \\
\hline & $\operatorname{Sgp} 2$ & 11530 & Tucker-1 & Bibb et al. (1981) \\
\hline Legionella maceachernii & & 11982 & PX-1-G2-E2 $2^{T}$ & Brenner et al. (1985) \\
\hline Legionella micdadei & & 11371 & TATLOCK ${ }^{\mathrm{T}}$ & Hébert et al. (1980) \\
\hline & & 11372 & PPA & Hébert et al. (1980) \\
\hline & & 11403 & HEBA & Hébert et al. (1980) \\
\hline Legionella oakridgensis & & 11531 & OR-10 $0^{\top}$ & Orrison et al. (1983) \\
\hline Legionella parisiensis & & 11983 & $\mathrm{PF}-209 \mathrm{C}-\mathrm{C} 2^{\mathrm{T}}$ & Brenner et al. (1985) \\
\hline Legionella rubrilucens & & 11987 & WA-270A-C $2^{\mathrm{T}}$ & Brenner et al. (1985) \\
\hline & & & $\mathrm{LC} 215$ & Author's unpublished data \\
\hline & & & LC216 & Author's unpublished data \\
\hline Legionella sainthelensi & & 11988 & Mt St Helens-4T & Campbell et al. (1984) \\
\hline Legionella santicrucis & & 11989 & $\mathrm{SC}-63-\mathrm{C} 7^{\mathrm{T}}$ & Brenner et al. (1985) \\
\hline Legionella spiritensis & & 11990 & Mt St Helens-9T & Brenner et al. (1985) \\
\hline & & 12082 & ML 76 & Author's unpublished data \\
\hline Legionella steigerwaltii & & 11991 & $\mathrm{SC}-18-\mathrm{C} 9^{\mathrm{T}}$ & Brenner et al. (1985) \\
\hline Legionella wadsworthii & & 11532 & $81-716 \mathrm{~A}^{\mathrm{T}}$ & Edelstein et al. (1982) \\
\hline Unnamed Legionella species A & & & $51-83(1308)$ & P. J. L. Dennis, pers comm. \\
\hline Unnamed Legionella species B & & & $59-84(1477)$ & P. J. L. Dennis, pers comm. \\
\hline Unnamed Legionella species C & & & $199-82(1224)$ & P. J. L. Dennis, pers comm. \\
\hline Unnamed Legionella species D & & & $200-83(1335)$ & P. J. L. Dennis, pers, comm. \\
\hline Unnamed Legionella species $\mathrm{E}$ & & & $95-83(1347)$ & P. J. L. Dennis, pers. comm. \\
\hline
\end{tabular}


Table 1 (continued)

(b) Strains identified by biochemical and serological methods $\dagger$

\begin{abstract}
Species/serogroup
Legionella pneumophila
\end{abstract}

Legionella bozemanii

Legionella dumoffii

Legionella gormanii

Legionella wadsworthii

Unnamed Legionella species C

Pseudomonas vesicularis
NCTC* Strain

Sgpl 11404 Bellingham-1

L.C 20

LC 28

Sgp5 11417 Cambridge-2

LC434

Sgp6 11287 Oxford-1

Sgp12 LC204

LC205

Sgp13 82A-3105

Sgp? IC419

I.C 213

LC318

LC 319

LC 320

LC 329

LC 377

LRU52

LRU68

LRU56

LRU81

LRU82

LRU83

LRU85

LC455

LC458

LC121

LC218a

LC221a

ML81
Source*

Clinical isolate/France

Clinical isolate/France

Fnvironmental isolate/UK

Environmental isolate/UK

Environmental isolate/UK $\}$

Environmental isolate/Singapore

Environmental isolate/France

Environmental isolate/UK

Environmental isolate/UK

Environmental isolate/UK

Environmental isolate/UK

Environmental isolate/UK

Environmental isolate/UK

Environmental isolate/UK

Environmental isolate/UK

Environmental isolate/UK

Clinical isolate/UK

Clinical isolate/UK

Clinical isolate/UK

Environmental isolate/Singapore

Environmental isolate/Singapore

Environmental isolate/France

Environmental isolate/UK

Environmental isolate/UK $\}$

Environmental isolate

$\mathrm{T}$. Type strain of the species.

* Catalogue numbers of strains available from the National Collection of Type Cultures (NCTC), 61 Colindale Avenue, London NW9 5HT, UK. Where strains are not available from the NCTC they are held in the culture collection of the Legionella Reference Unit.

+ Brenner et al. (1985).

\$ Strains bracketted together are epidemiologically related.

$\S$ Serological variant of undetermined serogroup.

established using biochemical and serological techniques (Table $1 b$ ) (Brenner et al, 1985). An environmental isolate submitted to this laboratory, as a possible Legionella, was shown by the use of a API 20ne identification kit to be a strain of Pseudomonas vesicularis. This strain was included in the panel of coded isolates.

For this study strains were considered to be epidemiologically related to each other if they were obtained from the same environmental source (although not necessarily at the same time), or were obtained from a patient exposed to that source. Strains for which there was no obvious link were considered to be epidemiologically unrelated.

Construction of a L. pneumophila genome library. DNA isolated from the Knoxville-1 strain of $L$. pneumophila was used to prepare a gene library in the vector $\lambda \mathrm{gtWES} . \lambda \mathrm{B}$. (Tiemeier et al., 1976) using methods described by Maniatis et al. (1982). The $\lambda \mathrm{B}$. fragment was excised with EcoRI and replaced by EcoRI restriction fragments (2$15 \mathrm{~kb}$ ) derived by complete digestion of the genomic DNA. Recombinant phage, resulting from in vitro packaging, were plated on E. coli NM531 (supE supF hsdR recA) (Kaiser \& Murray, 1985).

Preparation of $16 S$ and $23 S \mathrm{SRNA}$ subunits. L. pneumophila (K noxville-1) cells were treated with lysozyme ( $3 \cdot 3 \mathrm{mg}$ $\mathrm{mi}^{-1}$ ) for $30 \mathrm{~min}$ at $37^{\circ} \mathrm{C}$ in buffer containing $25 \%$ (w/v) sucrose. $50 \mathrm{~mm}-\mathrm{Tris} / \mathrm{HCl}, \mathrm{pH} 8.0$. The cells were recovered by centrifugation and RNA was prepared (Saunders \& Grant, 1984). The 16S and 23S rRNA subunits were purified on a linear 5-20\% (w/v) sucrose gradient in $10 \mathrm{mM}-\mathrm{HEPES} / \mathrm{NaOH}, \mathrm{pH} 7 \cdot 5$, by centrifugation at $125000 \mathrm{~g}_{\mathrm{as}}$, for $16 \mathrm{~h}$ in a SW60Ti rotor (Beckman).

Screening for $r R N A$ genes. The library was screened by plaque filter hybridization (Maniatis et al., 1982) on nylon filters (Hybond-N; Amersham). The probe was prepared from a mixture of $16 \mathrm{~S}$ and $23 \mathrm{~S}$ rRNAs derived from $L$. pneumophila (Knoxville-1) which were subjected to polynucleotide kinase labelling with [ $\gamma^{32}$ P]ATP (Amersham) following partial alkaline hydrolysis (Maniatis et al, 1982). 
Preparation of bacterial DNA. DNA was extracted using a propan-2-ol precipitation method (Owen \& Borman, 1987). Briefly, the pellet of bacterial cells was resuspended in buffer containing $150 \mathrm{mM}-\mathrm{NaCl}, 15 \mathrm{mM}-\mathrm{EDTA}$, $50 \mathrm{~mm}$-Tris/ $\mathrm{HCl}, \mathrm{pH} 8.0$ and RNAase A $\left(50 \mu \mathrm{g} \mathrm{ml}^{-1}\right.$; Sigma) and lysed by addition of SDS to $1 \%(\mathrm{w} / \mathrm{v})$. The lysate was allowed to clear at $37^{\circ} \mathrm{C}$ for $15-30 \mathrm{~min}$ and then proteinase $\mathrm{K}$ (Sigma) was added $\left(0 \cdot 1 \mathrm{mg} \mathrm{ml}^{-1}\right)$ and incubated for a further $30 \mathrm{~min}$. The protease treated lysate was then extracted with chloroform : isoamyl alcohol $(24: 1, \mathrm{v} / \mathrm{v})$ and made to $2.5 \mathrm{M}$ in ammonium acetate by addition of a $7.5 \mathrm{M}$ stock solution. The extracted DNA was precipitated by addition of propan-2-ol ( 0.54 vols), collected by centrifugation and washed twice in $70 \%(\mathrm{v} / \mathrm{v})$ ethanol. The final pellet was dried in vacuo and resuspended in TE buffer (10 mM-Tris/HCl, $\mathrm{pH} 8 \cdot 0,1 \mathrm{~mm}-\mathrm{EDTA})$.

Restriction endonuclease digestion and agarose-gel electrophoresis. Bacterial DNA $(1-2 \mu \mathrm{g})$ was digested with $N c i \mathrm{I}$ (2-4 units) (Northumbria Biologicals), or HaeIII (2-4 units) (Amersham) in medium salt buffer (Maniatis et al., 1982) for $2 \mathrm{~h}$ at $37^{\circ} \mathrm{C}$. The restriction fragments were separated by electrophoresis in $0 \cdot 8 \%(\mathrm{w} / \mathrm{v})$ or $1 \cdot 2 \%(\mathrm{w} / \mathrm{v})$ agarose gels at $20 \mathrm{~V}\left(1 \mathrm{~V} \mathrm{~cm}^{-1}\right)$ for $18 \mathrm{~h}$ in Tris/borate buffer $(0.089 \mathrm{M}$-Tris, $0.089 \mathrm{M}$-boric acid, 0.002 M-EDTA) containing $0.5 \mu \mathrm{g}$ ethidium bromide $\mathrm{ml}^{-1}$. Bacteriophage $\lambda$ (strain $c \mathrm{I} 857$ ts $\operatorname{Sam} 7$ ) DNA fragments, derived by cleavage with PstI and EcoRI, were run as molecular size standards. Following electrophoresis the gel was soaked for $1 \mathrm{~h}$ each in denaturing solution $(0.5 \mathrm{M}-\mathrm{NaOH}, 1.5 \mathrm{M}-\mathrm{NaCl})$ and then in neutralizing solution $(1 \mathrm{M}-\mathrm{Tris} / \mathrm{HCl}, \mathrm{pH}$ $8 \cdot 0,1 \cdot 5 \mathrm{M}-\mathrm{NaCl})$.

Southern transfer of DNA samples. Southern transfer of DNA was done as described by Maniatis et al. (1982) using nylon filters (Hybond-N ; Amersham). The filters were air-dried, covered in Mobilrapper II (Mobil Plastics, Virton, Belgium) and exposed to longwave UV light $(3 \mathrm{~min})$ from a transilluminator (UV Products) to effect covalent binding of the DNA fragments to the solid phase.

Preparation of $\lambda$ phage $D N A$. Bacteriophage particles were purified from a lysed culture by the pelleting method (Maniatis et al., 1982). DNA was released from phage, suspended in SM buffer ( $50 \mathrm{mM}-\mathrm{Tris} / \mathrm{HCl}, \mathrm{pH} 7 \cdot 5,0 \cdot 1 \mathrm{M}-$ $\mathrm{NaCl}, 10 \mathrm{~mm}-\mathrm{MgSO}_{4}$ and $0.01 \%$, w/v, gelatin), by addition of $0.5 \mathrm{M}$-EDTA (pH 8.0) to $20 \mathrm{mM}$, proteinase $\mathrm{K}$ to $50 \mu \mathrm{g} \mathrm{ml}^{-1}$, SDS $(20 \%, \mathrm{w} / \mathrm{v})$ to $0.5 \%$ followed by incubation at $65{ }^{\circ} \mathrm{C}$ for $1 \mathrm{~h}$. The DNA was purified by successive extractions with phenol, phenol/chloroform/isoamyl alcohol $(25: 24: 1$, by vol. and chloroform/isoamyl alcohol $(24: 9, \mathrm{v} / \mathrm{v})$. The DNA in the aqueous phase was precipitated with ethanol in the presence of $0.3 \mathrm{M}$-sodium acetate, pH 6.0, washed twice with $70 \%(\mathrm{v} / \mathrm{v})$ ethanol and dried in vacuo. At this stage the $\lambda$ DNA was unsuitable for restriction endonuclease digestion or for labelling reactions. Contaminating materials were removed by further treatment with RNAase and proteinase $\mathrm{K}$ followed by extraction with chloroform and precipitation with propan2-ol as described above for the purification of bacterial DNAs. In our hands this modified procedure gives high yields of $\lambda$ DNA $\left.[>1 \mu \mathrm{g} \text { (ml culture })^{-1}\right]$ which is both pure, as determined by gel electrophoresis followed by ethidium bromide staining, and a good substrate for restriction endonucleases and DNA polymerase $I$.

Labelling and hybridization of probe. $\lambda 142$ DNA was labelled by primer extension using biotin-11-dUTP (Gibco). The labelled DNA was separated from unincorporated dNTPs by spun column chromatography (Maniatis et al., 1982). Southern blots were prehybridized for $3 \mathrm{~h}$ and then hybridized for $18 \mathrm{~h}$ at $42{ }^{\circ} \mathrm{C}$ in hybridization solution $[45 \%, \mathrm{v} / \mathrm{v}$, formamide, $5 \times$ SSPE $(1 \times$ SSPE is $0 \cdot 15 \mathrm{~m}-\mathrm{NaCl}, 1 \mathrm{~mm}$-EDTA, $10 \mathrm{~mm}$-sodium phosphate $/ \mathrm{NaOH}, \mathrm{pH}$ $7.4), 5 \times$ Denhardt's solution ( $1 \times$ Denhardt's solution is $0.02 \% \mathrm{BSA}, 0.02 \% \mathrm{PVP}, 0.02 \% \mathrm{Ficoll}), 0.1 \%$, w $/ \mathrm{v}, \mathrm{SDS}$, $100 \mu \mathrm{g}$ denatured herring sperm DNA ml${ }^{-1}$ ] containing labelled probes $(150 \mathrm{ng})$, denatured by heating $\left(100^{\circ} \mathrm{C}\right.$ for $5 \mathrm{~min})$. Following incubation the filters were washed at low-stringency in $2 \times \mathrm{SSC}, 0.1 \%(\mathrm{w} / \mathrm{v}) \mathrm{SDS}$ at $50{ }^{\circ} \mathrm{C}(2 \times$ $15 \mathrm{~min}$ and $1 \times 30 \mathrm{~min}$ ) as described in Maniatis et al. (1982). The filters were then air-dried and hybridized sequences detected using the Blu-gene system (Gibco).

Northern Blotting. RNA from L. pneumophila (Knoxville-1) was subjected to agarose-gel electrophoresis ( $1 \%$, $\mathrm{w} / \mathrm{v}$, gel) in the presence of formaldehyde and blotted onto nylon filters (Maniatis et al., 1982). The blot was hybridized to $\lambda 142$, which had been labelled by nick-translation (Rigby et al., 1977) with $\left[\alpha-{ }^{32}\right.$ P]dCTP (Amersham). The bound probe was detected by autoradiography using Kodak X-Omat AR film and intensifying screens.

DNA fragment size estimation. The molecular size (in base pairs) of restriction fragments was calculated from a standard curve of relative mobility against molecular size of the EcoRI and $P s t$ restriction fragments of $\lambda$ phage, which were run on each gel.

\section{RESULTS}

\section{Selection and characterization of a $r R N A$ gene probe}

When the L. pneumophila gene library was screened with end-labelled rRNA fragments, approximately $0.5 \%$ of the clones gave a strong positive signal indicating hybridization to cloned rRNA sequences. One of these clones $(\lambda 142)$ was purified and used to probe a Northern blot of $L$. pneumophila RNA. Both the 23S and 16S rRNA species hybridized to the probe and gave a signal proportional to the quantity of rRNA subunits in the RNA preparation (Fig. 1). The smaller RNA molecules including 5S and TRNA were removed by washing with 3 M-sodium 


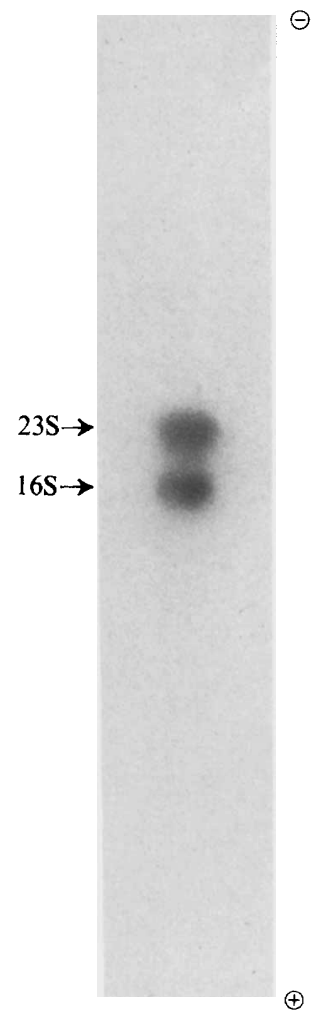

Fig. 1. Northern blot analysis of $\lambda 142$. Total RNA from $L$. pneumophila Knoxville-1 $(5 \mu \mathrm{g})$ was run on a $1 \%$ agarose gel, then blotted and hybridized to ${ }^{32} \mathrm{P}$-labelled $\lambda 142$; following washing under stringent conditions the bands were visualized by autoradiography.

acetate during preparation; consequently, it is not known whether sequences encoding these subunits are present on $\lambda 142$. These results demonstrate the proximity of the two genes and suggest that the rRNA genes of $L$. pneumophila are clustered. If this is the case then $\lambda 142$ must include the complete sequence of at least one ribosomal subunit since the cloned fragment is larger than a single rRNA gene cluster. It is also likely that a high proportion of the complete sequence of both major rRNA molecules is present since the hybridization signal obtained was proportional to the quantity of $16 \mathrm{~S}$ and $23 \mathrm{~S}$ subunits in the RNA preparation.

\section{Restriction endonuclease digestion of DNA from legionellae}

DNA preparations from all isolates in Table 1, except the three strains of $L$. micdadei, were efficiently cleaved by the restriction endonuclease $N c i$. Although resistant to digestion with NciI the L. micdadei DNAs were susceptible to digestion with HaeIII (see Fig. 3). The DNA preparations obtained from the isolate of Legionella species A appeared to be highly susceptible to $\mathrm{Ncil}$ yielding a very high proportion of small restriction fragments. This suggests that the $\mathrm{mol} \% \mathrm{G}+\mathrm{C}$ of Legionella species A is relatively high. A similar result was observed for the DNA from $P$. vesicularis, which has a $\mathrm{mol} \% \mathrm{G}+\mathrm{C}$ of $65 \cdot 8$ (Palleroni, 1984).

\section{Analysis of the restriction fragment patterns obtained}

Examination of the restriction fragments detected by probing the blots of NciI or HaeIII digested DNAs revealed these to be species specific. Thus distinct patterns were obtained for the 28 type strains examined. A selection of these patterns is shown in Fig. $2(\mathrm{NciI})$ and Fig. 3 (HaeIII). None of the 81 isolates examined gave the same pattern as another isolate belonging to a different species. Epidemiologically distinct isolates belonging to the same species gave patterns which were indistinguishable from those of the type strain in the cases of $L$. pneumophila (five isolates), $L$. anisa (five isolates), $L$. micdadei (two isolates), $L$. feeleii (one isolate), $L$. 


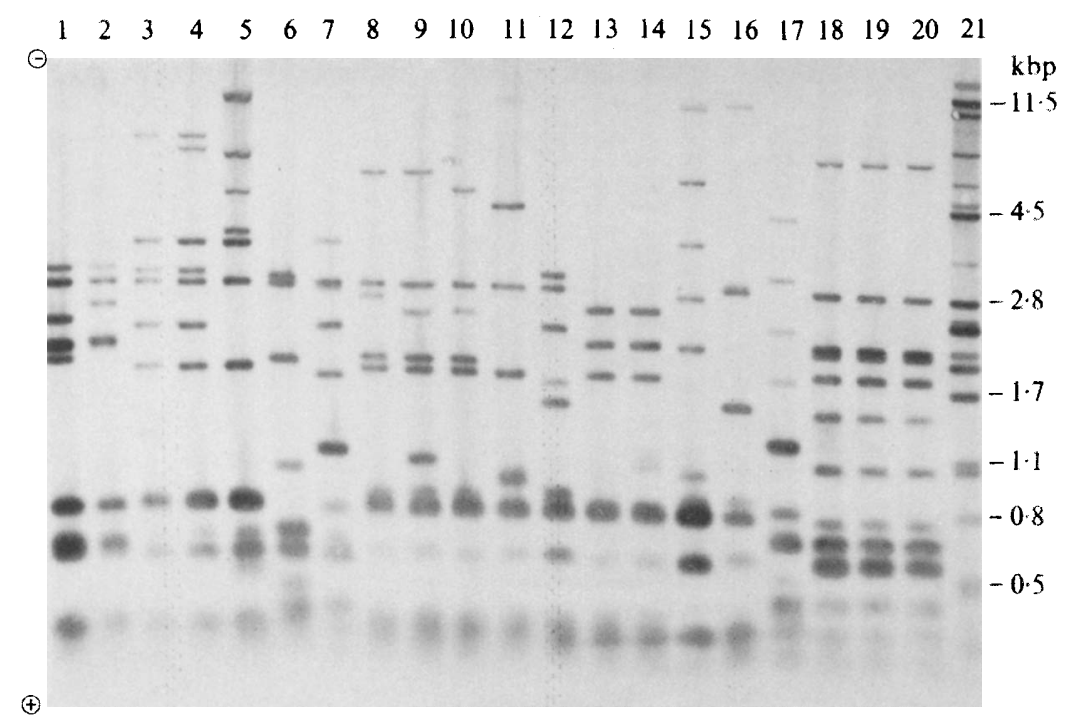

Fig. 2. NciI restriction fragments from Legionella species detected with the probe $\lambda 142$. Restriction fragments ( $1 \mu \mathrm{g}$ per track), derived by $N c$ I digestion of DNA from Legionella species, were subjected to electrophoresis on a $0.8 \%$ agarose gel at $1 \mathrm{~V} \mathrm{~cm}^{-1}$ for $16 \mathrm{~h}$. The DNA was blotted and hybridized to biotinylated $\lambda 142(150 \mathrm{ng})$. Bound probe was visualized using the Blu-gene kit reagents. Tracks $1-20$ show the patterns obtained for 19 strains as follows: 1, L. pneumophila Knoxville-1; 2, L. pneumophila LC20: 3, L. longbeachae Long Beach-4; 4. L. longbeachae Tucker-1; 5, L. sainthelensi Mt St Helens-4; 6, L. spiritensis Mt St Helens-9; 7, L. oukridgensis OR-10;8, L. bozemanii WIGA; 9, L. bozemanii MI-15: 10, L. bozemanii Toronto-3; 11, L anisa WA-316-C 3; 12, L. gormanii LS-13; 13, L dumoffi NY-23; 14, L. dumoffii Tex-KL; 15, L. steigerwaltii SC-18-C9; 16, L. cherrii ORW; 17, L. israelensis Bercovier-4; 18 and $19, L$. hackeliae Lansing-2; 20, L. hackeliae 798-PA-H. Restriction fragments of $\lambda$ phage (2 ng) are shown in track 21 .

hackeliae (one isolate), L. spiritensis (one isolate), Legionella species C (one isolate), L. wadsworthii (one isolate), L. dumoffii (one isolate). L. gormanii (one isolate), or differed in the position of a single band, or in the presence/absence of a single band, in the cases of $L$. rubrilucens (two isolates), L. dumoffii (one isolate), L. longbeachae (one isolate), L. erythra (one isolate).

In the case of $L$. bozemanii strains MI-15 and Toronto-3 (serogroup 2) both showed two restriction fragment length polymorphisms (RFLPs) from the type strain WIGA, and a further group of related isolates (LRU81, LRU82, LRU83 and LRU85) shared the same pattern as WIGA. This diversity in pattern might be expected from the low sequence homology in this species (Brenner et al., 1980).

Examination of 22 strains of $L$. pncumophila belonging to the 13 recognized serogroups provided the best opportunity to assess the degree of variation between restriction sites within a species. Fig. 4 shows the results of analysis of 15 strains (the banding patterns of the other seven strains are not presented here). All 22 strains had the same pattern of bands of molectular size $<0.8 \mathrm{kbp}$ and also shared a fragment at $2.8 \mathrm{kbp}$. Twenty of the strains also had bands at $2.0 \mathrm{kbp}$ and 19 of these had a further restriction fragment at $3.0 \mathrm{kbp}$. A $1.8 \mathrm{kbp}$ band was present in 1.5 strains. Six strains, including the type strain of L. pneumophila (Philadelphia-1), had only these four bands $(1.8,2.0,2.8$ and $3.0 \mathrm{kbp})$ of $>0.8 \mathrm{kbp}$. Track 9 (Fig. 4) shows an example of this pattern. Four more strains had the pattern described above but with one additional band at $2 \cdot 3$ kbp. This group included Knoxville-1, the strain from which the probe sequence was derived (track 2). A further four isolates had all of the type strain bands together with other variable features. Five of the remaining strains had the $2 \cdot 0,2.8$ and $3.0 \mathrm{kbp}$ fragments and at least one other band. The serogroup 11 type strain (797-PA-H), shown in track 12 , gave a pattern including the $1 \cdot 8,2.0$ and $2.8 \mathrm{kbp}$ species together with two other major bands. Two strains gave 


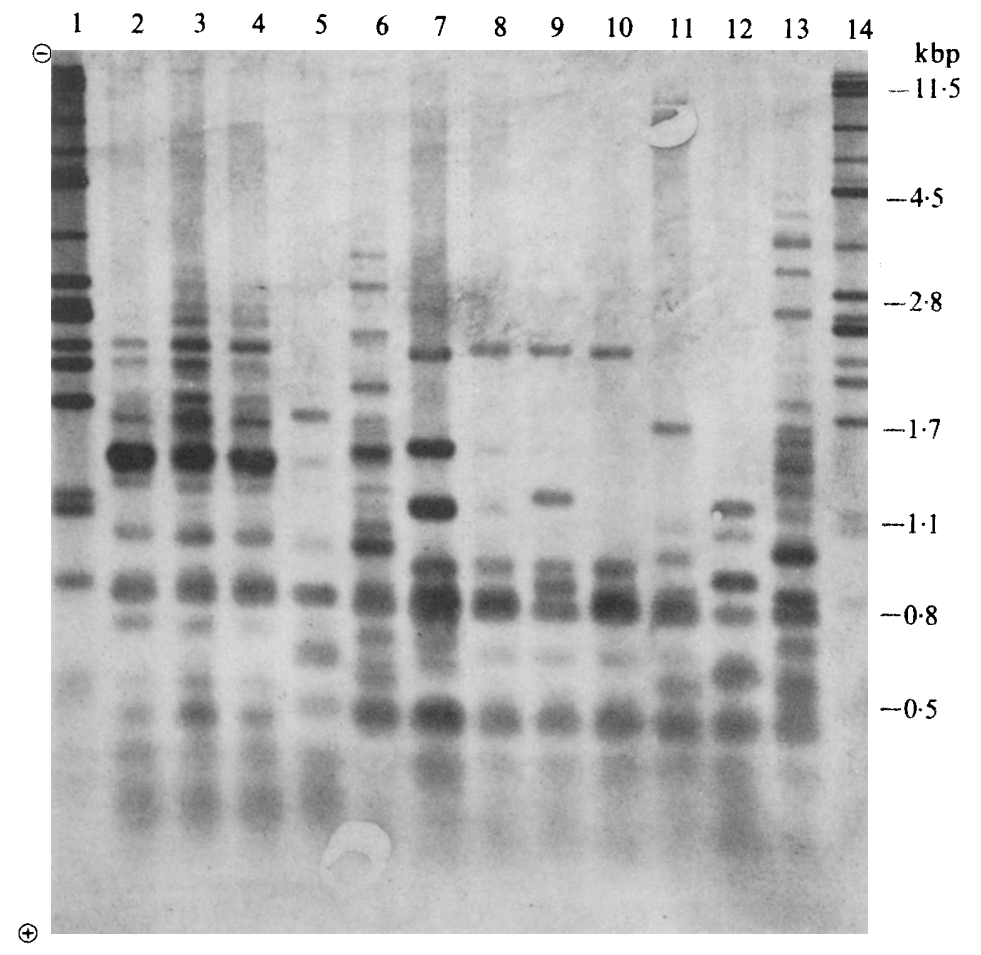

Fig 3. HaellI restriction fragments from Legionella species detected with the probe $\lambda 142$. Restriction fragments ( $1 \mu \mathrm{g}$ per track), derived by HaeIII digestion of DNA from Legionella species, were subjected to electrophoresis on a $1.2 \%$ agarose gel at $1 \mathrm{~V} \mathrm{~cm}^{-1}$ for $16 \mathrm{~h}$. The DNA was blotted and hybridized to biotinylated $\lambda 142(150 \mathrm{ng})$. Bound probe was visualized using the Blu-gene kit reagents. Tracks $2-13$ show the patterns obtained for 12 strains as follows: $2, L$. micdadei PPA; 3, L. micdadei HEBA; $4, L$. micdadei TATLOCK ; 5, L. maceachernii PX-1-G2-E2; 6, L. cherrii ORW; 7, L. pneumophila K noxville1; 8, L. bozemanii MI-15; 9, L. bozemanii WIGA; 10, L. bozemanii Toronto-3; 11, L. anisa WA-316-C3; 12, L. parisiensis PF-209C-C2:13, L, steigerwaltii SC-18-C9. Restriction fragments of $\lambda$ phage are shown in tracks $1(2 \mathrm{ng})$ and $14(1 \mathrm{ng})$.

rather different patterns having only the $<0.8$ and $2.8 \mathrm{kbp}$ bands in common with Philadelphia1. These isolates (Los Angeles-1 and Dallas-1E) shared two other fragments at 1.9 and $2.3 \mathrm{kbp}$.

\section{Identification of 'unknown' legionellae}

To determine whether the method could be used to identify the species of a putative legionella, 31 isolates (which had been examined previously) were coded by one of us (T.G.H.) and identification was then attempted (by N. A.S.). The pattern obtained for each coded isolate was compared against those previously obtained for each species and thus the identity of the coded isolate was determined. All of the coded isolates were susceptible to digestion with $N c i$ I. Of the 31 strains 23 were epidemiologically unrelated. Seventeen of these isolates were indistinguishable on the basis of restriction fragments from previously examined strains of known identity. These isolates were correctly identified as L. pneumophila (four isolates), L. anisa (six isolates), $L$. bozemanii (one isolate), Legionella species C (one isolate), L. spiritensis (one isolate) $L$. wadsworthii (one isolate), $L$. dumoffii (one isolate) and $L$. gormanii (one isolate). Five other isolates gave patterns similar to but distinct from those of type strains of various Legionella species. Two of these were correctly identified as L. pneumophila on the basis of the presence of bands at $2.0,2.8$ and $3.0 \mathrm{kbp}$. Another pair of isolates were identified as $L$. rubrilucens, the restriction fragments differing only in the position of a single band, compared with those from $L$. rubrilucens (WA-270A-C2). The fifth isolate, previously identified serologically as $L$. rubrilucens, 


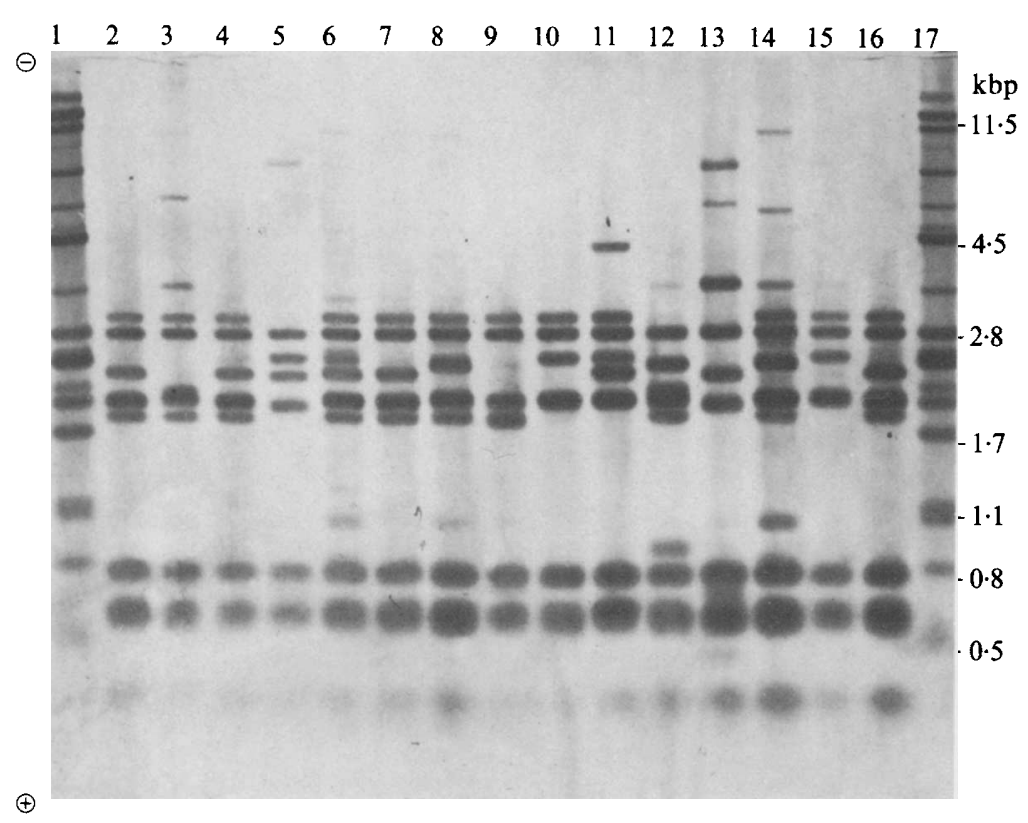

Fig. 4. Analysis of 15 strains of $L$. pneumophila. Restriction fragments $(1 \mu \mathrm{g}$ per track), derived by $N c i \mathrm{I}$ digestion of DNA from $L$. pneumophila, were subjected to electrophoresis on a $0.8 \%$ agarose gel at $1 \mathrm{~V}$ $\mathrm{cm}^{-1}$ for $16 \mathrm{~h}$. The DNA was blotted and hybridized to biotinylated $\lambda 142(150 \mathrm{ng})$. Bound probe was visualized using the Blu-gene kit reagents. Tracks $2-16$ show the patterns obtained for 15 strains as follows: 2, Knoxville-1 ; 3, Togus-1; 4, Bloomington-2; 5, Los Angeles-1; 6, Cambridge-2; 7, Oxford-1 ; 8, Chicago-8; 9, Concord-3; 10, IN-23-G1-C2; 11, Leiden-1 ; 12, 797-PA-H ; 13, Dallas-1E; 14, LC28; 15 , LC20;16, Bellingham-1. Restriction fragments of $\lambda$ phage $(2 \mathrm{ng})$ are shown in tracks 1 and 17.

gave a pattern of fragments at $<0.8 \mathrm{kbp}$, which was consistent with either of the recognized red autofluorescent species ( $L$. rubrilucens or L. erythra). However, this strain (LC217) was identified as $L$. erythra on the basis of the positioning of bands of higher molecular size. This identification was subsequently confirmed by DNA/DNA hybridization studies, using a filter method (Johnson, 1981). LC217 showed 96\% homology with L. erythra (SE-32A-C8) DNA at low stringency (in the same experiment three L. rubrilucens strains - WA-270A-C2, LC215 and LC216 - gave values of 35 to $42 \%$ homology to $L$. erythra). At $10^{\circ} \mathrm{C}$ below the melting temperature of $L$. erythra DNA (stringent conditions) the homology value dropped to $83 \%(L$. rubrilucens 9 to $13 \%$ ). Two isolates could not be assigned to a species.

Five groups of epidemiologically related strains were examined. These comprised $L$. pneumophila (two isolates), L. anisa (two groups of two and three isolates each), L. bozemanii (four isolates), Legionella species C (two isolates). The isolates within each group gave indistinguishable patterns.

\section{DISCUSSION}

Ribosomal RNA genes are highly conserved and present in multiple copies in the chromosomes of bacterial species. These properties make them particularly suitable for the studies presented here. The conserved nature of the rRNAs allows a single probe to be used in studies of the entire genus (Legionella) and offers the possibility that species-specific patterns will be obtained. The presence of multiple copies of the rRNA genes increases the sensitivity, and power to discriminate between species, of the method. A similar procedure based on the use of 5 -end- ${ }^{32} \mathrm{P}$-labelled E. coli $16 \mathrm{~S}$ and $23 \mathrm{~S}$ rRNA as a probe has been published (Grimont et al., 1987). The cloned rRNA gene used in the study presented here has several advantages over the use of rRNA subunits as a probe. Firstly, DNA cloned in $\lambda$ can readily be purified in quantity. The method used here compares favourably with the lengthy procedure for the preparation of 
rRNA subunits. Secondly, the cloned DNA is of highly consistent quality. Thirdly, since the cloned fragment appears to represent a cluster of rRNA genes there is likely to be an equal proportion of sequences for the rRNA subunits $(5 \mathrm{~S}, 16 \mathrm{~S}$ and $23 \mathrm{~S}$ ) available for hybridization to target sequences. Fourthly, the vector sequences of the probe hybridize to $\lambda$ fragments run on tracks adjacent to samples of Legionella DNA and these provide ideal molecular size standards allowing the species patterns to be compared from one gel to another. A possible disadvantage of the cloned probe used in this study is the presence of DNA sequences flanking the rRNA genes. However, it was considered that these sequences would not hybridize to species other than $L$. pneumophila because of the low DNA homologies between Legionella species. In the case of $L$. pneumophila the flanking sequences could cause some variation in the patterns due to their hybridization to non-rRNA gene sequences. In practice this did not appear to be a serious problem (Fig. 4).

Although DNA preparations from 27 Legionella species were satisfactorily digested with $N c i$ I, DNA from all three $L$. micdadei strains was refractory to cleavage with this enzyme. This is probably because of methylation of the DNA in this species at the internal cytosine residue of the $N c i$ site. One of these strains (TATLOCK) has been shown to have a restriction enzyme activity (Chen et al., 1986), which presumably acts at the NciI recognition site.

Ncil recognizes the sequence $5^{\prime}-\mathrm{CC}_{\mathrm{C}}^{\mathrm{GG}} \mathrm{3}^{\prime}$ and was expected to have many sites of cleavage within the rRNA gene cluster of $\lambda 142$. This consideration was critical since intra-species sequence variations within the highly conserved rRNA genes are relatively uncommon whilst the sequences of the flanking DNA would be expected to be more variable. In this regard it is expected that the method using $\mathrm{Nci}$ I described here will be more useful than that described by P. A. D. Grimont and colleagues for Legionella species identification, where restriction endonucleases having hexanucleotide recognition sequences are used (Grimont \& Grimont, 1986; Grimont et al., 1987). A method based on sequence differences in the flanking DNA (as would be the case when the recognition sites of the restriction enzyme chosen are widely spaced) would be expected to yield a greater proportion of intra-species differences in patterns of restriction fragments. This would be undesirable since it would then be difficult to identify unknown isolates. It might be possible to further reduce the influence of the variable flanking sequences by using a nuclease which recognizes many sites within the rRNA gene cluster. This is demonstrated in Fig. 3 for HaeIII; however, the small restriction fragments thus generated yield relatively unclear patterns which are difficult to interpret.

The results obtained using the restriction fragment length analysis technique with the rRNA gene probe on a number of isolates of $L$. pneumophila shows that some restriction sites are conserved whilst others are more variable in position, suggesting that some of the sequences hybridizing to the probe are more variable than others. It would be expected that these nonconserved restriction sites correspond either to the flanking sequences or to parts of the rRNA gene which are less conserved. Variable sequences are known to be present in parts of the bacterial 16S rRNA sequence (Woese et al., 1983). It is worthy of note that studies of DNA relatedness and isoenzyme patterns indicate that $L$. pneumophila is a relatively diverse species at both the genotypic and phenotypic levels (Brenner et al., 1978; Selander et al., 1985). Some evidence was obtained in this study that the more distantly related strains of $L$. pneumophila give rise to divergent patterns. For example, Los Angeles-1 and Dallas-1E (Fig. 4, tracks 5 and 13), two strains belonging to a subset of isolates described as Species 1 by Selander et al. (1985), gave similar patterns of restriction fragments which were distinct from those of the other isolates of $L$. pneumophila examined.

Comparison of the results obtained for the 22 L. pneumophila strains examined in this study, with those of previous work involving 48 serogroup 1 strains of this species, probed with a nonribosomal sequence (Saunders et al., 1987), shows the advantage of using rRNA sequences as probes for species identification. Many fewer RFLPs are revealed by the rRNA gene probe sequence and consequently less intra-species pattern variations occur.

The results of testing 'unknown' coded isolates show the utility of this method. In most cases (24 out of 31 ) the pattern obtained was indistinguishable from that of at least one strain, of 
known identity, which had been examined previously. In these cases the unknown was accurately identified. In three further instances the pattern differed in the position of a single band and it was possible to assign these isolates to the correct species with a high level of confidence. In two instances the patterns obtained from the DNA of 'unknowns' had strong similarities to the pattern obtained from an isolate of a known species and the tentative identification of these strains was found to be correct. In practice, positive identification of isolates in this category will rely on further data. Two isolates were not assigned to a species. One, a non-Legionella species, was subsequently shown to be an isolate of Pseudomonas vesicularis. The second, a serologically unusual environmental isolate from Singapore, was characterized as a L.pneumophila strain on the basis of biochemical tests and its reaction with a species specific monoclonal antibody (Genetic Systems). The restriction fragment pattern obtained was unusual, although the bands typical of this species at $3.0,2.0$ and $<0.8 \mathrm{kbp}$ were present, fragments of 2.8 and $1.8 \mathrm{kbp}$ in size were absent. No DNA/DNA hybridization data are available for this isolate, but it may be that both the atypical restriction fragment pattern and serological results obtained correlate to low genome homology with the type strain. However, it must be recognized that a novel pattern of bands could result from analysis of a Legionella isolate with subtle base sequence differences compared with previously examined isolates of that species. This is because RFLPs can result from a single base deletion or substitution. Alternatively, a novel pattern can represent a previously unreported Legionella species or a nonLegionella isolate. Consequently a novel pattern yields little useful information.

It is clear that the method described in this paper will be of considerable value in studies on the legionellae and should provide a valuable complement to both the current biochemical and serological methods (which may provide inconclusive data), and DNA/DNA hybridization, which is technically demanding and time-consuming. For example, using the probe, it was relatively simple to distinguish between the blue-white autofluorescent species, $L$. anisa, $L$. bozemanii, L. steigerwaltii, L. cherrii, L. dumoffi, L. gormanii and L. parisiensis. Among these species it is particularly useful to be able to distinguish $L$. anisa from $L$. bozemanii and $L$. steigerwaltii from $L$. cherrii as these pairs of genospecies can otherwise be reliably split only by measurement of percentage divergence in DNA hybridization studies. It is anticipated that as more strains are examined and the database of RFLPs expands, a greater proportion of isolates will be identified with a high degree of confidence.

\section{REFERENCES}

Bercovier, H., Steigerwalt, A. G., Derhi-Cochin, M., Moss, C. W., Wilkinson, H. W., Benson, R. F. \& BRENNER, D. J. (1986). Isolation of legionellae from oxidation ponds and fishponds in Israel and description of Legionella israelensis sp. nov. International Journal of Systematic Bacteriology 36, 368-371.

Bibb, W. F., Sorg, R. J., Thomason, B. M., Hicklin, M. D., Steigerwalt, A. G., Brenner, D. J. \& WULF, M. R. (1981). Recognition of a second serogroup of Legionella longbeachae. Journal of Clinical Microbiology 14, 674-677.

Bibb, W. F., Arnow, P. M., Dellinger, D. L. \& Perryman, S. R. (1983). Isolation and characterization of a seventh serogroup of Legionella pneumophila. Journal of Clinical Microbiology 17, 346--348.

Bissett, M. L., LEE, J. O. \& LiNDQuist, D. S. (1983). New serogroup of Legionella pneumophila, serogroup 8. Journal of Clinical Microbiology 17, 887-891.

Brenner, D. J. (1986). Classification of Legionellaceae: current status and remaining questions. Israel Journal of Medical Science 22, 620-632.

Brenner, D. J., Steigerwalt, A. G., Weaver, R. E., MCDade, J. E., Feeley, J. C. \& Mandel, M. (1978). Classification of the Legionnaires' disease bac- terium: an interim report. Current Microbiology 1 , $71-75$.

Brenner, D. J., Steigerwalt, A. G. \& McDade, J. E (1979). Classification of the Legionnaires' disease bacterium: Legionella pneumophila, genus novum, species nova, of the family Legionellaceae familia nova. Annals of Internal Medicine 90, 656-658.

Brenner, D. J., Steigerwalt, A. G., Gorman, G. W., Weaver, R. E., Feeley, J. C., Cordes, L. G., Wilkinson, H. W., Patton, C., Thomason, B. M. \& SASSEville, K. R. L. (1980). Legionella bozemanii $\mathrm{sp}$. nov. and Legionella dumoffi $\mathrm{sp}$. nov.: classification of two additional species of Legionella associated with human pneumonia. Current Microbiology 4, 111-116.

Brenner, D. J., Steigerwalt, A. G., Gorman, G. W., Wilkinson, H. W., BibB, W. F., HaCkel, M., Tyndall, R. L., Campbell, J., Feeley, J. C., Thacker, W. L., Skaliy, P., Martin, W. T., Brake, B. J., Fields, B. S., McEachern, H. V. \& Corcoran, L. K. (1985). Ten new species of Legionella. International Journal of Systematic Bacteriology 35, 50-59.

Campbell, J., Bibb, W. F., Lambert, M. A., Eng, S., 
Steigerwalt, A. G., Allard, J., Moss, C. W. \& BRENNER, D. J. (1984). Legionella sainthelensi: a new species of Legionella isolated from water near Mt. St. Helens. Applied and Environmental Microbiology 47, 369-373.

Chen, G. C., Brown, A. \& Lema, M. W. (1986). Restriction endonuclease activities in the legionellae. Canadian Journal of Microbiology 32, 591-593.

Cherry, W. B., Gorman, G. W., Orrison, L. H., Moss, C. W., Steigerwalt, A. G., Wilkinson, H. W., Johnson, S. E., MCKinney, R. M. \& BRENNER, D. J. (1982). Legionella jordanis: a new species of Legionella isolated from water and sewage. Journal of Clinical Microbiology 15, 290-297.

Edelstein, P. H., Brenner, D. J., Moss, C. W., Steigerwalt, A. G., Francis, E. M. \& George, W. L. (1982). Legionella wadsworthii species nova: a cause of human pneumonia. Annals of Internal Medicine 97, 809-813.

Edelstein, P. H., Bibb, W. F., Gorman, G. W., Thacker, W. L., BrenNer, D. J. Wilkinson, H. W., Moss, C. W., Buddington, R. S., DunN, C. J., Roos, P. J. \& MeEnhorst, P. L. (1984). Legionella pneumophila serogroup 9: a cause of human pneumonia. Annals of Internal Medicine 101, 196198.

England, A. C., McKinney, R. M., Skaliy, P. \& Gorman, G. W. (1980). A fifth serogroup of Legionella pneumophila. Annals of Internal Medicine 93, 58-59.

Gorman, G. W., Feeley , J. C., Steigerwalt, A. G., Edelstein, P. H., Moss, C. W. \& Brenner, D. J. (1985). Legionella anisa: a new species of Legionella isolated from potable waters and a cooling tower. Applied and Environmental Microbiology 49, 305-309.

Grimont, F. \& GRIMoNT, P. A. D. (1986). Ribosomal ribonucleic acid gene restriction patterns as potential taxonomic tools. Annales de l'Institut Pasteur/ Microbiologie 137B, 165-175.

Grimont, F., Lefevre, M., \& Grimont P. A. D. (1987). Taxonomie des Legionella. In Colloque Legionella 6-7th Mai 1987, pp. 3-7. Edited by J. Fleurette, N. Bornstein, D. Marmet \& M. Surgot. Lyon: Fondation Merieux.

Hébert, G. A., Steigerwalt, A. G. \& Brenner, D. J. (1980). Legionella micdadei species nova: classification of a third species of Legionella associated with human pneumonia. Current Microbiology 3, 255-257.

Herwaldt, L. A., Gorman, G. W., McGrath, T., Toma, S., Brake, B., Hightower, A. W., Jones, J., Reingold, A. L., BoXer, P. A., TANG, P. W., Moss, C. W., Wilkinson, H. W., BRENNER, D. J., Steigerwalt, A. G. \& Broome, C. V. (1984). A new Legionella species, Legionella feeleii species nova, causes Pontiac fever in an automobile plant. Annals of Internal Medicine 100, 333-338.

JoHNsON, J. L. (1981). Genetic characterization. In Manual of Methods for General Bacteriology, pp. 446448. Edited by P. Gerhardt, R. G. Murray, R. N. Costilow, E. W. Nester, W. A. Wood, N. R. Krieg \& G. B. Phillips. Washington, DC: American Society for Microbiology.

KaISER, K. \& Murray, N. E. (1985). The use of phage lambda vectors in the construction of representative genomic DNA libraries. In DNA Cloning, vol. 1, pp. 1-47. Edited by D. M. Glover. Oxford: IRL Press.
Maniatis, T., Fritsch, E. F. \& Sambrook, J. (1982). Molecular Cloning: a Laboratory Manual, pp. 320 326. Cold Spring Harbor, NY: Cold Spring Harbor Laboratory.

MCKinney, R. M., Thacker, L., Harris, P. P., Lewallen, K. R., Hebert, A., Edelstein, P. H. \& Thomason, B. M. (1979). Four serogroups of Legionnaires' disease bacteria defined by direct immunofluorescence. Annals of Internal Medicine $\mathbf{9 0}$, 621-624.

MCKinney, R. M., Wilkinson, H. W., SOMmers, H. M., Fikes, B. J., Sasseville, K. R., Yungbluth, M. M. \& WoLF, J. S. (1980). Legionella pneumophila serogroup six : isolation from cases of legionellosis, identification by immunofluorescence staining, and immunological response to infection. Journal of Clinical Microbiology 12, 395-401.

MCKinney, R. M., PorsChen, R. K., Edelstein, P. H., Bissett, M. L., Harris, P. P., Bondell, S. P., Steigerwalt, A. G., Weaver, R. E., Ein, M. E., Lindquist, D. S., KoPS, R. S. \& BRENNER, D. J. (1981). Legionella longbeachae species nova, another etiologic agent of human pneumonia. Annals of Internal Medicine 94, 739-743.

MeEnhorst, P. L., Reingold, A. L., Groothuis, D. G., Gorman, G. W., Wilkinson, H. W., MCKINNEY, R. M., FEeley, J. C., BRENNER, D. J. \& VAN FURTH, R. (1985). Water-related nosocomial pneumonia caused by Legionella pneumophila serogroups 1 and 10. Journal of Infectious Diseases 152 , 356-364.

Morris, G. K., Steigerwalt, A. G., Feeley, J. C., Wong, E. S., Martin, W. T., Patton, C. M. \& BRENNER, D. J. (1980). Legionella gormanii sp. nov. Journal of Clinical Microbiology 12, 718-721.

Orrison, L. H., Cherry, W. B., Tyndall, R. L., Fliermans, C. B., Gough, S. B., Lambert, M. A., McDougal, L. K., BibB, W. F. \& Brenner, D. J. (1983). Legionella oakridgensis; unusual new species isolated from cooling tower water. Applied and Environmental Microbiology 45, 536-545.

OWen, R. J. \& Borman, P. (1987). A rapid biochemical method for purifying high molecular weight bacterial chromosomal DNA for restriction enzyme analysis. Nucleic Acids Research 15, 3631.

Palleroni, N. J. (1984). Family 1. Pseudomonadaceae. In Bergey's Manual of Systematic Bacteriology, vol. 1, p. 184. Edited by N. R. Krieg. Baltimore: Williams \& Wilkins.

Rigby, P. W., Dieckmann, M., Rhodes, C. \& Berg, P. (1977). Labelling deoxyribonucleic acid to high specific activity in vitro by nick translation with DNA polymerase 1. Journal of Molecular Biology 113, 237-251.

Saunders, N. A. \& Grant, M. E. (1984). Elastin biosynthesis in chick-embryo arteries. Biochemical Journal 221, 393-400.

Saunders, N. A., Kachwalla, N., Harrison, T. G. \& TAYLOR, A. G. (1987). Typing of Legionella pneumophila for epidemiological studies using DNA probes. In Colloque Legionella 6-7 Mai 1987, pp. 197-203. Edited by J. Fleurette, N. Bornstein, D. Marmet \& M. Surgot. Lyon: Fondation Merieux.

Selander, R. K., MCKinney, R. M., Whittam, T. S., Bibb, W. F., Brenner, D. J., Nolte, F. S. \& Pattison, P. E. (1985). Genetic structure of popula- 
tions of Legionella pneumophila. Journal of Bacterio$\log y 163,1021-1037$.

Tang, P. W., Toma, S., Moss, C. W., Steigerwalt, A. G., Cooligan, T. G. \& Brenner, D. J. (1984). Legionella bozemanii serogroup 2: a new etiological agent. Journal of Clinical Microbiology 19, 30-33.

Thacker, W. L., Wilkinson, H. W., Plikaytis, B. B., Steigerwalt, A. G., MayberRy, W. R., Moss, C. W. \& BRENNER, D. J. (1985). Second serogroup of Legionella feeleii strains isolated from humans. Journal of Clinical Microbiology 22, 1-4.

Thacker, W. L., Benson, R. F., Wilkinson, H. W. Ampel, N. M., Wing, E. J., Steigerwalt, A. G. \& BRENNER, D. J. (1986). 11 th serogroup of Legionella pneumophila isolated from a patient with fatal pneumonia. Journal of Clinical Microbiology 23, 1146-1147.
Thacker, W. L., Wilkinson, H. W., Benson, R. F. \& BRENNER, D. J. (1987). Legionella pneumophila serogroup 12 isolated from human and environmental sources. Journal of Clinical Microbiology 25, 569570.

Tiemeier, D., Enquist, L. \& Leder, P. (1976). Improved derivative of a phage EK2 vector for cloning recombinant DNA. Nature, London 263, 526-527.

Wilkinson, H. W., Thacker, W. L., Steigerwalt, A. G., Brenner, D. J., Ampel, N. M. \& Wing, E. J. (1985). Second serogroup of Legionella hackeliae isolated from a patient with pneumonia. Journal of Clinical Microbiology 22, 488-489.

Woese, C. R., Gutell, R. \& Noller, H. F. (1983). Detailed analysis of the higher-order structure of 16S-like ribosomal ribonucleic acids. Microbiological Reviews 47, 621-669. 